\title{
Jó 14,13-17: \\ significado teológico em seu contexto histórico-social
}

Orientadora: Maria de Lourdes Corrêa Lima

Mestranda: Ednea Martins Ornella

Área de Concentração: Teologia Bíblica

Linha de Pesquisa: Análise e Interpretação de Textos do Antigo e Novo Testamento

Este trabalho estuda o texto de Jó 14,13-17, considerando sua data de redação, de forma a permitir a compreensão do contexto e consequente significado teológico. Com a datação do texto, as fontes históricas, bíblicas e não bíblicas permitem concluir o contexto histórico, econômico, social e religioso da época, e suas implicações na vida do povo de Israel. Comenta-se o significado dos termos e expressões usados no texto poético. Estabelece-se, então, o que motivou o autor a desejar ser escondido no sheol, por tempo determinado, até YHWH desistir de sua ira e voltar a se recordar dele. Analisa-se, também, como a doutrina da retribuição influenciou o conflito que surgiu no meio da comunidade e como ele foi enfrentado. A poesia de Jó 14,13-17 é parte do esforço desenvolvido para solução dos conflitos sociais causados pela miséria e sofrimento do povo. Enquadra-se no contexto do trabalho pastoral que conclamou a classe social alta a uma atitude de solidariedade, como resposta à convocação de YHWH ao homem.

Palavras-chave: Teologia bíblica; exegese do Antigo Testamento; literatura sapiencial. 